\title{
Clinical features and diagnosis of alimentary endocrine tumours
}

\author{
R. B. WELBOURN
}

From the Royal Postgraduate Medical School, Hanmersmith Hospital, Du Cane Road, London W12 OHS

The alimentary tract is the largest endocrine factory in the body. The different types of endocrine cells, their distribution in the gastrointestinal tract, and their products are illustrated in Fig. 1. Some of the peptides and amines which are produced are established hormones, exerting physiological control of bodily functions, while the roles of others have not yet been determined. Some are produced by one organ only (for example insulin and glucagon by the pancreas), while others originate in more than one part of the gastrointestinal tract (for example gastrin from both the gastric antrum and the upper small intestine, and 5HT from three types of cell in the stomach and upper small intestine, two of which also produce peptides). Whereas some of these substances are truly endocrine in nature, others, such as VIP, somatostatin, and probably $5 \mathrm{HT}$, may have local actions as neurotransmitters or paracrine substances. All of them, however, when produced in excessive amounts by tumours enter the blood stream and may exert general effects.

All of these cells belong to Pearse's APUD series, and hyperplasia and neoplasia of the APUD cells are referred to as apudomas, a term which emphasises the common features of these lesions (Welbourn, 1977). Neoplasms may be single or

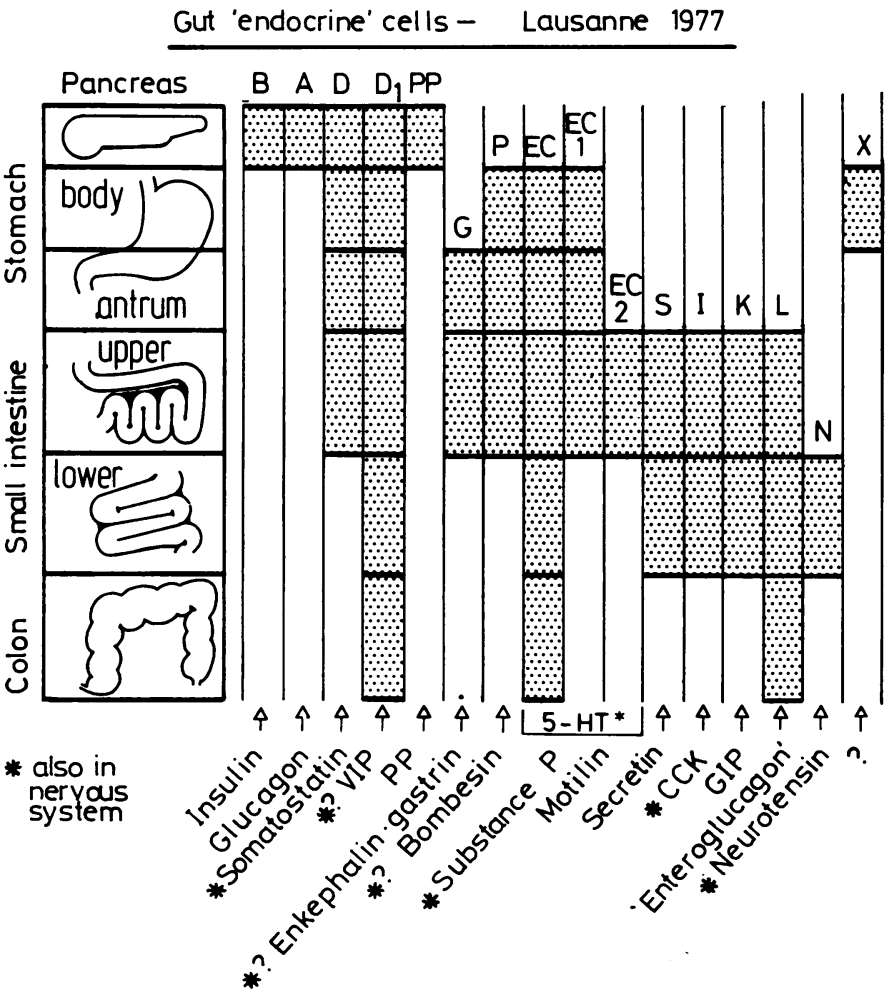

Fig. 1 Distribution of endocrine cells in the gastrointestinal tract. Names of cells are designated by letters and numbers at heads of columns. Hatched areas show their distribution in organs, but give no indication of their relative numbers. VIP, vasoactive intestinal polypeptide (although present in the pancreas, its origin there is probably from neural tissue and not from $D_{1}$ cells); PP, pancreatic polypeptide; $5 H T$, 5-hydroxytryptamine; $C C K$, cholecystokinin; GIP, glucose-dependent insulin-releasing peptide. (Derived from Solcia et al., 1978). 
multiple and take the form of adenoma, adenomatous hyperplasia, carcinoid, or carcinoma. All may secrete peptides or amines or both. Their secretory capacity is great and versatile, and tumours often secrete more than one product, although often only one of them causes metabolic and clinical effects, the rest for some reason being silent (Creutzfeldt, 1977; Welbourn et al., 1978).

The apudomas can be classified as orthoendocrine when they secrete the normal polypeptide or amine hormones of their cells of origin, or they may be paraendocrine ${ }^{\mathbf{1}}$, secreting hormones which are characteristic of other endocrine cells. Those which are known to be important clinically are the various islet cell tumours of the pancreas, carcinoid tumours, and gastrinomas of the stomach and duodenum. Possibly there are others which await description.

\section{Orthoendocrine apudomas of the pancreas}

Secretory tumours, arising from the $\mathrm{B}, \mathrm{A}, \mathrm{D}$, or PP cells of the pancreatic islets, take the form of insulinomas, glucagonomas, somatostatinomas, and PPomas, respectively. Vipomas, although consisting of endocrine-type cells, may arise from neural tissue rather than $D_{1}$ cells.

\section{THE INSULINOMA}

This tumour is well known, but uncommon. Characteristically, patients suffer from Whipple's triad, namely attacks of nervous or gastrointestinal disturbance coming on in the fasting state, associated with hypoglycaemia and relieved immediately by oral or intravenous glucose. Although the diagnosis is not difficult if it is entertained, the tumour is so rare that it is often overlooked. The great majority of patients are misdiagnosed at first and are often thought to suffer from nervous or mental disease. In one series half the patients were at some time thought to be epileptic (Welbourn, 1965). Mental features are often very striking and patients are apt to present the most bizzare behaviour, some of them being admitted to mental hospitals.

The diagnosis depends on the finding of an inappropriate relationship between glucose and insulin. Normally these rise and fall together, but in organic hyperinsulinism the hypoglycaemia is accompanied by high or normal (instead of low) insulin levels. Hypoglycaemia may be induced by prolonged fasting, and various provocative tests may be useful on occasions (Frerichs and Creutzfeldt, 1976; Marks, 1976). Of these tumours, $90 \%$ are

1 Not to be confused with 'paracrine', which refers to the secretion of a substance which normally has only a local action. single and benign and are cured by one operation $\frac{\stackrel{0}{\vec{\sigma}}}{\underline{\underline{\sigma}}}$ (Edis et al., 1976).

\section{THE GLUCAGONOMA}

This tumour was well described in 1966 by McGavran et al., but it has only been recognised at all commonly $\frac{\bar{s}}{\vec{D}}$ in recent years, since the development of a radio- $\overparen{D}$ immunoassay for glucagon and the consequent $\cong$ thorough characterisation of the syndrome (Mallin- son et al., 1974; Higgins et al., 1979).

Characteristically, patients suffer from migratory $\vec{\omega}$

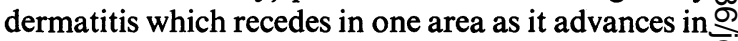
another, painful glossitis, angular stomatitis, often mild anaemia, diabetes, and loss of weight. Patients is are very prone to deep venous thrombosis and a few ọ have diarrhoea. If the syndrome is suspected it can be diagnosed easily by radioimmunoassay of $c$ plasma glucagon, the levels being 5 to 10 times? greater than the upper limit of normal (Holst, 1978). The dermatitis sometimes responds temporarily to treatment with steroids or zinc, suggesting that zinc deficiency may play some part in the patho- $\frac{\hat{2}}{2}$ genesis of the syndrome (Mallinson et al., 1977). About one third of these tumours are single and benign and should be readily curable by surgice्্्فl operation (Higgins et al., 1979).

\section{THE SOMATOSTATINOMA}

Two cases have been described in which somato- $\frac{0}{\varnothing}$ statin appeared to be the only, or the main, peptide $\stackrel{\mathbb{2}}{2}$ product (Ganda and Soeldner, 1977; Ganda et al., $\overrightarrow{\overrightarrow{0}}$ 1977; Larsson et al., 1977). The common features 3 were that both patients were women aged about 50 years and had diabetes. The tumours appeared to be composed of $\mathrm{D}$ cells and both had metastasised. Other possible components of the syndrome, manifest in only one of these patients, are hypo- 3 . chlorhydria and steatorrhoea. In the one patient in whom the tumour was removed the diabetes was $₹$ cured. Considering the number of hormones whose 0 function somatostatin inhibits, the metabolic and clinical possibilities are clearly great, and theo syndrome will not be defined adequately until more patients have been described.

\section{THE VIPOMA}

These tumours cause watery diarrhoea hypokalaemia, and achlorhydria (or, more commonly hypochlorhydria), a combination often called the $\frac{\mathbb{\Phi}}{\complement}$ WDHA (or WDHH) syndrome or pancreatic? cholera. It was first described in 1958 by Verner and 0 Morrison in association with islet cell tumours of $\vec{P}$ the pancreas, and VIP was first identified in such a疋 tumour in 1973 (Bloom et al., 1973). A raised level $\stackrel{Q}{\square}$ of VIP in the blood is almost diagnostic of the 


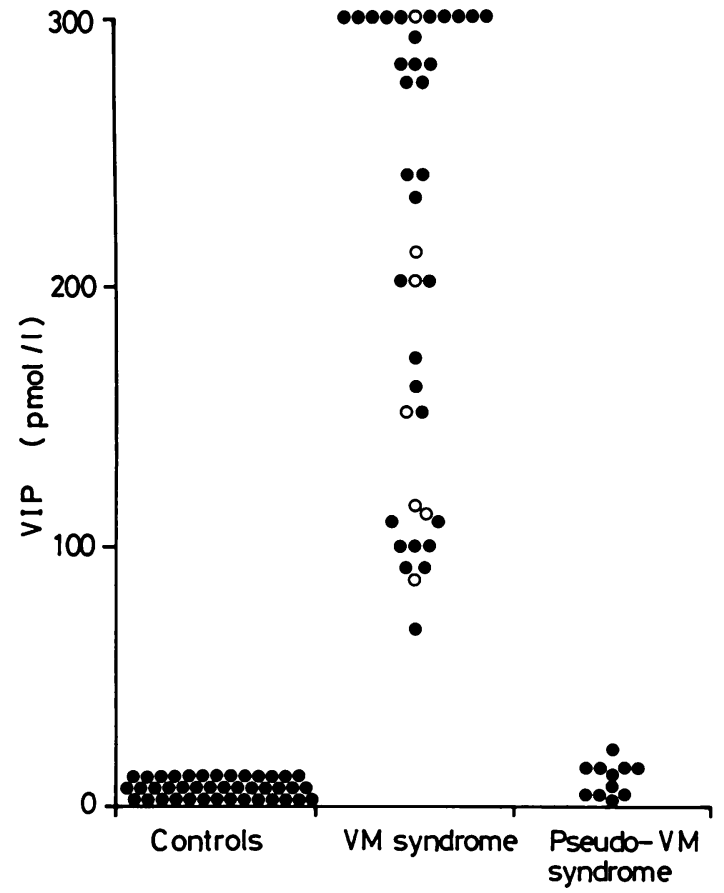

Fig. 2 Plasma VIP concentrations in normal subjects (controls), the first samples received from 39 patients found to have a vipoma in the pancreas $(\bullet)$ or a neural tumour ( 0 ) (VM syndrome), and patients suffering from the WDHA syndrome but without a tumour (pseudo-VM syndrome). (From Bloom, 1978).

condition (Fig. 2). About one half of the tumours are benign and could be cured by operation if they were diagnosed early enough. It is now known that certain neural tumours, in particular the ganglioneuromas and the neuroblastomas, also produce VIP, which is one of the peptides produced both by gut and by neural tissue, and that this causes the diarrhoea and hypokalaemia which sometimes accompany such tumours (Bloom, 1978). These patients also have high levels of VIP in the blood. A few patients exhibit the same WDHA syndrome without any discoverable tumour and without raised levels of VIP in the blood.

THE PANCREATIC-POLYPEPTIDOMA (PPOMA) Three tumours in which PP appeared to be the only peptide present were described by Polak and Bloom (Welbourn et al., 1978). None of them had any characteristic features other than those of a pancreatic tumour. One patient, whose tumour was situated close to the pancreatic duct, had steatorrhoea, but this may have been because of blockage of the duct. The absence of diarrhoea is important because it has been proposed that PP is the agent responsible for the features of the WDHA syndrome (Larsson et al., 1976).

Immunofluorescence studies have shown the presence of separate PP-containing cells in many tumours secreting other peptides (Polak et al., 1976). It appears to be produced by nearly half of pancreatic apudomas, especially by vipomas and glucagonomas, and by about the same proportion of carcinoids; it is also produced, but not so often, by insulinomas and gastrinomas. Raised levels were not found in the blood of over 50 patients with adenocarcinomas of non-endocrine tissues. High-blood levels of PP therefore form a useful marker for the presence of pancreatic apudomas and carcinoids (Adrian et al., 1978).

\section{Paraendocrine apudomas of the pancreas}

These tumours produce peptides or amines which are characteristic not of the pancreatic cells themselves but of other endocrine cells (Welbourn et al., 1978). The commonest, and the best known, is the gastrinoma producing the Zollinger-Ellison syndrome. Others secrete corticotrophin, antidiuretic hormone, parathyroid hormone, calcitonin, 5HT, etc, alone or in various combinations, causing appropriate syndromes.

\section{THE GASTRINOMA}

Gastrin secreted by this tumour is carried in the general circulation to the parietal cells of the stomach, which it stimulates to produce excessive amounts of hydrochloric acid. This causes duodenal or jejunal ulceration. In the early descriptions of the syndrome (Zollinger and Craig, 1960) the ulceration was extremely severe and often characterised by rapid recurrence after an operation considered to have been adequate for a duodenal ulcer. The severe complications of bleeding, perforation, fistulae, and so on were common and the syndrome was often fatal. In the last decade the picture has changed (Thompson et al., 1975; Regan and Malagelada, 1978). The patients now tend to be younger, have shorter histories, and are diagnosed earlier. The reasons are that the syndrome is better known, so that clinical suspicion is high, and that gastrin assays are readily available. A history of previous operations is now less common than hitherto, the ulcers are less likely to be in abnormal sites such as the jejunum, and are in fact often indistinguishable from ordinary idiopathic duodenal ulcers.

The diagnosis of this syndrome (Lamers and Van Tongeren, 1977) depends primarily on the finding of 
a high level of gastrin in the blood in the fasting state. The injection of secretin intravenously may also be helpful; in normal subjects there is no effect on the pl sma gastrin level except, possibly, a slight fall, but in patients with gastrinomas the plasma gastrin rises by at least $50 \%$ in 5 minutes. The results are not always clear cut, but in the great majority of patients the diagnosis can be made reliably by these tests.

Treatment by removal of the tumour alone is only occasionally successful, since most of them are malignant and tend to metastasise early. The removal of the whole of the acid-bearing area of the stomach by total gastrectomy was soon found to be the only effective way of relieving the symptoms in these patients. Although the tumours are often malignant, many of them grow slowly and patients may survive in reasonable health for years.

The introduction of cimetidine has, in the last 2 or 3 years, provided an alternative method of treatment. This cures ulceration in the great majority of patients and has led to a return to the idea of first controlling the ulcer and then attempting radical removal of the pancreatic tumour (Stadil and Stage, 1978). Cimetidine is also effective in healing the ulceration before total gastrectomy.

\section{OTHER PARAENDOCRINE APUDOMAS OF}

THE PANCREAS

These commonly produce multiple hormones, as detected by immunological methods, not all of which are biologically active. For example, one patient (Joffe et al., 1978) had high blood levels of ACTH and MSH, which were said to be immunochemically distinct, and of gastrin; all were present in the tumour. Only the ACTH, however, was biologically active, producing an acute Cushing's syndrome. Despite the extremely high level of circulating gastrin, the hypersecretion of acid and peptic ulceration characteristic of the ZollingerEllison syndrome were absent. Electronmicroscopy combined with immunocytochemistry showed that the gastrin and the ACTH were present in different cells, the ACTH in cells containing larger granules and the gastrin in those containing smaller ones.

\section{Orthoendocrine apudomas of the stomach and intestines}

Carcinoid tumours, which arise from the enterochromaffin cells, are the commonest of all the apudomas of the gut. Gastrinomas arise occasionally in the duodenum, where they are often single and benign, and very rarely in the stomach (Welbourn, 1977).
THE CARCINOID TUMOUR

This, unlike the previous tumours, characteristically produces a normal amine, 5-hydroxytryptamine $\stackrel{5}{+}$ (5HT), the enzyme kallikrein, often a prostaglandin E, and sometimes substance P (Kaplan, 1978). It is usually found in the appendix, where it is benign and is removed incidentally, the next most common site being the ileum. Its secretions are usually is metabolised in the liver and so cause no general metabolic effects, but when the liver contains metastases their products enter the general circulation and cause the malignant carcinoid syndrome. The major features of this are a characteristic flush 8 coming on after eating or taking alcohol, diarrhoea, is bronchospasm, and pulmonary stenosis which is its o. most sinister feature. The diagnosis depends $\vec{\oplus}$ primarily on the finding of increased excretion in or the urine of 5-hydroxyindolylacetic acid, the final 을 metabolite of 5HT. The quantities are greater than $80 \mu \mathrm{mol} / 24 \mathrm{~h}$ and often over 1000. The blood levels of prostaglandin and PP may be raised and these measurements are helpful sometimes in the diagnosis.

\section{Multiple endocrine adenopathy (MEA) type 1}

In this syndrome (Harrison and Thompson, 1975 hyperplasia or, less commonly, adenoma of the parathyroids is associated with a pituitary tumour, an islet cell tumour of any type, and sometimes with $\triangle$ a carcinoid in the intestine. Duodenal ulceration $\bar{a}$ occurs frequently even in the absence of a gastrinoma.

\section{Diagnosis of apudomas}

The diagnosis of these apudomas requires a

Clinical state Possible apudoma

\begin{tabular}{ll} 
Clinical state & Possible apudoma \\
\hline Peptic ulcer disease & $\begin{array}{l}\text { Parathyroid adenoma or hyperplasia; } \\
\text { gastrinoma }\end{array}$ \\
Diarrhoea & $\begin{array}{l}\text { Carcinoid tumour; vipoma; } \\
\text { gastrinoma; medullary carcinoma of } \\
\text { thyroid }\end{array}$ \\
Parathyroid adenoma or hyperplasia; \\
enteroglucagonoma
\end{tabular}

Table Clinical clues to diagnosis of apudomas arising from or affecting the gut

Adapted from Welbourn (1977). 
knowledge of the syndromes which have been described, a high index of suspicion, and use of the appropriate investigations. A check-list of features which should arouse suspicion is given in the Table.

Once the presence of an apudoma has been established, various methods are available for its localisation. A primary tumour in the pancreas may be sought by various forms of radiography, ultrasonography, and computerised tomography. Scinti- graphy is also helpful for the detection of secondary deposits in the liver. Selective arteriography (Fig. 3) is particularly helpful for pancreatic tumours (Edis et al., 1976). Selective venous sampling (Ingemansson et al., 1977) may be helpful (Fig. 4a, b), but is sometimes misleading and not without danger. A very rapid radioimmunoassay for insulin may also be used to analyse such venous samples while the operation is proceeding (Turner et al., 1978).

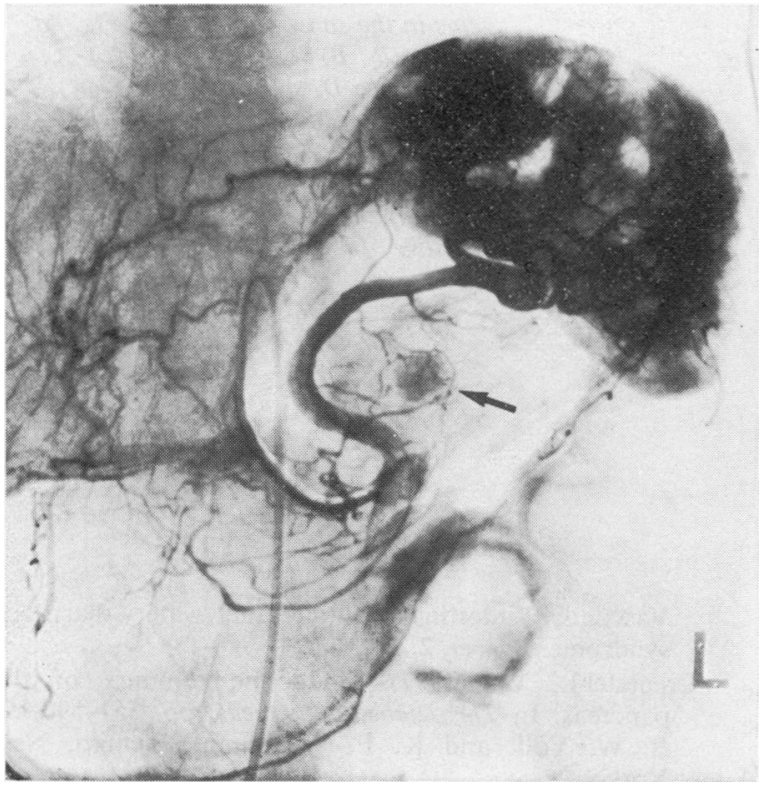

Fig. 3 Selective splenic arteriogram with subtraction of background showing an insulinoma (arrow) in the body of the pancreas. (A subtraction picture is one in which the tissue shadowing not resulting from the arteriogram is removed by a photographic manipulation.) (By courtesy of Dr D. J. Allison.)

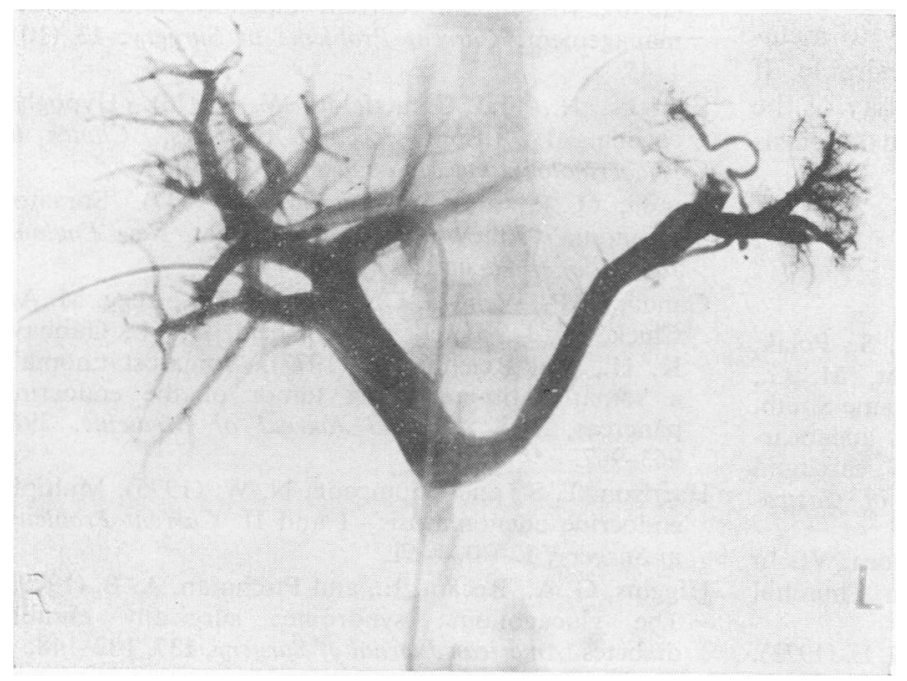

Fig. 4a Percutaneous, transhepatic venogram of the portal and splenic veins and percutaneous, transcaval hepatic venogram (shown faintly) in the same patient as in Fig. 3, to show the distribution of the vessels. (By courtesy of $\operatorname{Dr}$ D.J. Allison.) 
Portal venous sampling Insulin levels ( $\mathrm{pmol} / \mathrm{l}$ )

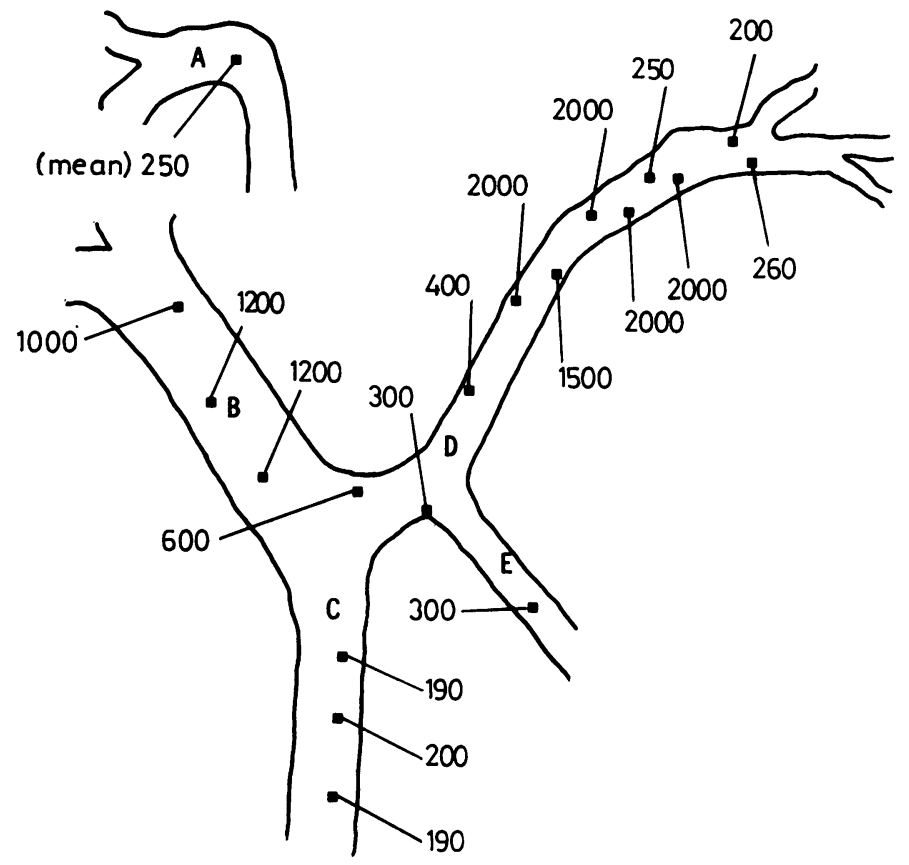

Fig. 4b Approximate concentration of insulin ( $p m o l / l)$ in blood from different veins in the same patient as in Fig. $4 a$. $A$, hepatic; $B$, portal; $C$, superior mesenteric; $D$, splenic; $E$, inferior mesenteric veins. Note the sudden increase from 200 to 2000 pmol ll in the splenic vein, corresponding to the tumour shown by arteriography (Fig. 3). (By courtesy of $\mathrm{Dr}$ D. J. Allison.)

\section{Conclusion}

These tumours are all rare, but the greater the awareness of them, the more likely they are to be diagnosed. The aim must be to diagnose them early, when surgical removal may cure patients with benign tumours. Unfortunately, many are malignant and may require chemotherapy, embolisation of the hepatic artery to reduce the blood supply to metastases, etc, but early diagnosis is still desirable. If clinical suspicion is high, radioimmunoassay of the hormones in plasma will make or refute the diagnosis in most patients.

\section{References}

Adrian, T. E., Bloom, S. R., Besterman, H. S., Polak, J. M., Pera, A., Modigliani, R., Bryant, M. G., Modlin, I. M., Barnardo, D. E., and Grahame-Smith, D. G. (1978). Pancreatic polypeptide in adenocarcinomas and apudomas including the carcinoid syndrome (Abst.). Scandinavian Journal of Gastroenterology, 13, Suppl. 49, 2.

Bloom, S. R. (1978). VIP and watery diarrhoea. VI. In Gut Hormones, pp. 583-588, ed S. R. Bloom. Churchill Livingstone, Edinburgh.

Bloom, S. R., Polak, J. M., and Pearse, A. G. E. (1973).
Vasoactive intestinal peptide and watery-diarrhoea syndrome. Lancet, 2, 14-16.

Creutzfeldt, W. (1977). Endocrine tumours of the pancreas. In The Diabetic Pancreas, pp. 551-590, ed B. W. Volk and K. F. Wellmann. Plenum, New York.

Edis, A. J., McIlrath, D. C., Van Heerden, J. A., Fulton, 용 R. E., Sheedy, P. F., Service, F. J., and Dale, A. J. D. 후 (1976). Insulinoma: current diagnosis and surgical management. Current Problems in Surgery, 13 (10), $1-45$.

Frericks, H., and Creutzfeldt, W. (1976). Hypoglycaemia. I. Insulin-secreting tumours. Clinics in Endocrinology and Metabolism, 5, 747-767.

Ganda, O. P., and Soeldner, J. S. (1977). 'Somatostatinoma': follow-up studies (Letter). New England No Journal of Medicine, 297, 1352-1353.

Ganda, O. P., Weir, G. C., Soeldner, J. S., Legg, M. A., Chick, W. L., Patel, Y. C., Ebeid, A. M., Gabbay, 心 K. H., and Reichlin, S. (1977). 'Somatostatinoma': O a somatostatin-containing tumor of the endocrine pancreas, New England Journal of Medicine, 296, 963-967.

Harrison, T. S., and Thompson, N. W. (1975). Multiple endocrine adenomatosis-I and II. Current Problems in Surgery, 12 (8), 1-51.

Higgins, G. A., Recant, L., and Fischman, A. B. (1979). The glucagonoma syndrome: surgically curable $\circ$ diabetes. American Journal of Surgery, 137, 142-148. 
Holst, J. J. (1978). Glucagonomas. In Gut Hormones, pp. 599-604, ed S. R. Bloom. Churchill Livingstone, Edinburgh.

Ingemansson, S., Kühl, C., Larsson, L. I., Lunderquist, A., and Nobin, A. (1977). Islet cell hyperplasia localized by pancreatic vein catheterization and insulin radioimmunoassay. American Journal of Surgery, 133, 643-645.

Joffe, S. N., Elias, E., Rehfeld, J. F., Polak, J. M., Bloom, S. R., and Welbourn, R. B. (1978). Clinically silent gross hypergastrinaemia from a multiple hormone-secreting pancreatic apudoma. British Journal of Surgery, 65, 277-280.

Kaplan, E. L. (1978). The carcinoid syndromes. In Surgical Endocrinology-Clinical Syndromes, pp. 120147, ed S. R. Friesen. Lippincott, Philadelphia.

Lamers, C. B. H., and Van Tongeren, J. H. M. (1977). Comparative study of the value of the calcium, secretin, and meal stimulated increase in serum gastrin to the diagnosis of the Zollinger-Ellison syndrome. Gut, 18, 128-135.

Larsson, L. I., Holst, J. J., Kühl, C., Lundqvist, G., Hirsch, M. A., Ingemansson, S., Lindkaer Jensen, S., Rehfeld, J. F., and Schwartz, T. W. (1977). Pancreatic somatostatinoma-clinical features and physiological implications. Lancet, 1, 666-668.

Larsson, L. I., Schwartz, T., Lundqvist, G., Chance, R. E., Sundler, F., Rehfeld, J. F., Grimelius, L., Fahrenkrug, J., Schaffalitzky de Muckadell, O., and Moon, N. (1976). Occurrence of human pancreatic polypeptide in pancreatic endocrine tumors. American Journal of Pathology, 85, 675-682.

McGavran, M. H., Unger, R. H., Recant, L., Polk, H. C., Kilo, C., and Levin, M. E. (1966). A glucagonsecreting alpha-cell carcinoma of the pancreas. New England Journal of Medicine, 274, 1408-1413.

Mallinson, C. N., Adrian, T. E., Hanley, J., Bryant, M., and Bloom, S. R. (1977). Metabolic and clinical responses in patients with pancreatic glucagonomas (Abst.). Irish Journal of Medical Science, 146, Suppl. 1, 37-38.

Mallinson, C. N., Bloom, S. R., Warin, A. P., Salmon, P. R., and Cox, B. (1974). A glucagonoma syndrome. Lancet, 2, 1-5.
Marks, V. (1976). Hypoglycaemia, 2. Other causes. Clinics in Endocrinology and Metabolism, 5, 769-782.

Polak, J. M., Adrian, T. E., Bryant, M. G., Bloom, S. R., Heitz, P., and Pearse, A. G. E. (1976). Pancreatic polypeptide in insulinomas, gastrinomas, vipomas and glucagonomas. Lancet, 1, 328-330.

Regan, P. T., and Malagelada, J. R. (1978). A reappraisal of clinical, roentgenographic, and endoscopic features of the Zollinger-Ellison syndrome. Mayo Clinic Proceedings, 53, 19-23.

Solcia, E., et al. (1978). Lausanne 1977 classification of gastroenteropancreatic endocrine cells. In Gut Hormones, pp. 40-48, ed S. R. Bloom. Churchill Livingstone, Edinburgh.

Stadil, F., and Stage, J. G. (1978). Cimetidine and the Zollinger-Ellison (Z-E) syndrome. In Cimetidine: the Westminster Hospital Symposium 1978, pp. 91-104, ed C. Wastell and P. Lance. Churchill Livingstone, Edinburgh.

Thompson, J. C., Reeder, D. D., Villar, H. V., and Fender, H. R. (1975). Natural history and experience with diagnosis and treatment of the Zollinger-Ellison syndrome. Surgery, Gynecology and Obstetrics, 140, 721-739.

Turner, R. C., Morris, P. J., Lee, E. C. G., Harris, E. A., and Dickl, R. (1978). Localisation of insulinomas. Lancet, 1, 515-518.

Verner, J. V., and Morrison, A. B. (1958). Islet cell tumor and a syndrome of refractory watery diarrhea and hypokalemia. American Journal of Medicine, 25, 374-380.

Welbourn, R. B. (1965). Surgical aspects of hypoglycaemia. Journal of the Royal College of Surgeons of Edinburgh, 10, 196-206.

Welbourn, R. B. (1977). Apudomas of the gut. American Journal of Surgery, 133, 13-22.

Welbourn, R. B., Polak, J. M., Bloom, S. R., Pearse, A. G. E., and Galland, R. B. (1978). Apudomas of the pancreas. In Gut Hormones, pp. 561-569, ed S. R. Bloom. Churchill Livingstone, Edinburgh.

Zollinger, R. M., and Craig, T. V. (1960). Ulcerogenic tumors of the pancreas. American Journal of Surgery, 99, 424-432. 